\title{
EFEK HEPATOPROTEKTIF SERBUK AKAR PASAK BUMI (Eurycoma longifolia Jack.) DILIHAT DARI AKTIVITAS SGPT- SGOT TIKUS JANTAN YANG DIINDUKSI $\mathrm{CCl}_{4}$
}

\author{
HEPATOPROTECTIVE EFFECT OF EURYCOMa \\ longifolia Jack. ROOTS POWDER ON SGPT-SGOT ACTIVITY ON \\ $\mathrm{CCl}_{4}$-INDUCED MALE RATS
}

\author{
Wirawan Adikusuma, Moch. Saiful Bachri \\ Fakultas Farmasi Universitas Ahmad Dahlan, \\ Jl. Prof. Dr. Soepomo, Janturan, Yogyakarta \\ Email:msaifulbachri@yahoo.co.id
}

\begin{abstract}
ABSTRAK
Penelitian ini bertujuan untuk mengetahui efek hepatoprotektif serbuk akar pasak bumi dilihat dari aktivitas SGPT-SGOT tikus jantan yang diinduksi $\mathrm{CCl}_{4}$. Dua puluh lima ekor tikus jantan (150-250 g) dibagi menjadi 5 kelompok. Kelompok I sebagai kelompok normal diberi aquadest, kelompok II sebagai kelompok kontrol diberi $\mathrm{CCl}_{4}$ dosis $1 \mathrm{ml} / \mathrm{kgBB}$, kelompok III dan IV diberi serbuk akar pasak bumi berturut-turut dosis $100 \mathrm{mg} / \mathrm{kgBB}, 200 \mathrm{mg} / \mathrm{kgBB}$ dan $\mathrm{CCl}_{4}$ dosis $1 \mathrm{ml} / \mathrm{kgBB}$, kelompok $\mathrm{V}$ diberi curcumin dosis $100 \mathrm{mg} / \mathrm{kgBB}$ dan $\mathrm{CCl}_{4}$ dosis 1 $\mathrm{ml} / \mathrm{kgBB}$. Darah diambil melalui vena porta untuk diuji aktivitas SGPT-SGOT. Hasil penelitian menunjukkan bahwa aktivitas SGPT dari tikus yang diberi serbuk akar pasak bumi dengan dosis $100 \mathrm{mg} / \mathrm{kgBB}$ dan $200 \mathrm{mg} / \mathrm{kgBB}$, Curcumin, dan kelompok kontrol berturut turut, 150,0 $\pm 5,099 \mathrm{U} / \mathrm{L} ; 113,6 \pm 5,508 \mathrm{U} / \mathrm{L} ; 60,5 \pm 2,887 \mathrm{U} / \mathrm{L} ;$ dan 129,0 $\pm 6,055$ U/L. Sedangkan aktivitas SGOT dari tikus yang diberi serbuk akar pasak bumi dengan dosis $100 \mathrm{mg} / \mathrm{kgBB}$ dan $200 \mathrm{mg} / \mathrm{kgBB}$, Curcumin, dan kelompok kontrol berturut turut, 369,4 $\pm 11,165$; 263,0 $\pm 1,803 ; 194,5 \pm 7,448$; and 451,5 $\pm 16,759$ U/L. Serbuk akar pasak bumi dan Curcumin secara signifikan $(\mathrm{p}<0,05)$ dapat menurunkan aktivitas SGPT dan SGOT dibanding kelompok kontrol. Dari hasil penelitian menunjukkan bahwa serbuk akar pasak bumi mempunyai efek hepatoprotektif.
\end{abstract}

Kata kunci : Eurycoma longifolia Jack., hepatoprotektif, SGPT-SGOT, $\mathrm{CCl}_{4}$.

\section{ABSTRACT}

This study was designed to evaluate the hepatoprotective effect of the powder Eurycoma longifolia Jack. From the activity level of SGPT-SGOT on $\mathrm{CCl}_{4}$-induced in male rats. Twenty five male rats (150-250 g) divide in to 5 groups. Group I treated with aquadest was kept as normal, group II treated with a single dose of $\mathrm{CCl}_{4}(1 \mathrm{ml} / \mathrm{kg}$ BW i.p), group III and IV were treated with Eurycoma longifolia Jack. (100 mg/kg BW and $200 \mathrm{mg} / \mathrm{kg}$ BW p.o) respectively and $\mathrm{CCl}_{4}(1 \mathrm{ml} / \mathrm{kg} \mathrm{BW}$ i.p), group $\mathrm{V}$ treated with a single dose of curcumin $(100 \mathrm{mg} / \mathrm{kg} \mathrm{BW}$ p.o) and $\mathrm{CCl}_{4}(1 \mathrm{ml} / \mathrm{kg}$ BW i.p). Blood was collected from vena porta for determination of SGPT-SGOT. The study showed the activity level of SGPT from the rats was treated by Eurycoma longifolia Jack. $100 \mathrm{mg} / \mathrm{kg} \mathrm{BW}$ and $200 \mathrm{mg} / \mathrm{kg} \mathrm{BW}$, Curcumin, and control groups

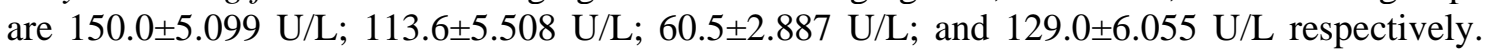


Mean while the activity level of SGOT from the rats was treated by Eurycoma longifolia Jack. $100 \mathrm{mg} / \mathrm{kg} \mathrm{BW}$ and $200 \mathrm{mg} / \mathrm{kg}$ BW, Curcumin, and control groups are 369.4 \pm 11.165 ; 263.0 $\pm 1.803 ; 194.5 \pm 7.448$; and 451.5 $\pm 16.759 \mathrm{U} / \mathrm{L}$ respectively. The Eurycoma longifolia Jack. powder and Curcumin significantly $(\mathrm{p}<0.05)$ declines two enzymes (SGPT and SGOT) than control group. The results concluded that Eurycoma longifolia Jack. powder has hepatoprotective effect.

Keywords : Eurycoma longifolia Jack., hepatoprotective, SGPT-SGOT, $\mathrm{CCl}_{4}$

\section{PENDAHULUAN}

Hati merupakan organ terbesar yang sangat penting untuk pertahanan hidup dan berperan hampir dalam setiap fungsi metabolik tubuh. Fungsi hati antara lain untuk pembentukan dan ekskresi empedu. Empedu dibentuk di dalam hati dan sekitar 1 liter empedu diekskresikan oleh hati dalam sehari. Di samping menghasilkan energi dan tenaga, hati memiliki peranan penting pada metabolisme karbohidrat, protein dan lemak, selain itu juga berperan dalam pertahanan tubuh, baik berupa detoksifikasi maupun fungsi perlindungan. Detoksifikasi dilakukan dengan berbagai proses yang dilakukan oleh enzim-enzim di hati terhadap zat-zat beracun. Fungsi perlindungan dilakukan oleh sel kupffer yang berada dalam dinding sinusoid (Price and Wilson, 2005).

Sel-sel hati sering sekali mengalami kerusakan. Kerusakan hati akibat senyawa kimia toksik, virus dan obat dapat menyebabkan kerusakan menetap pada sel-sel hati yang berakibat pada peradangan (hepatitis) ataupun kematian sel-sel hati (nekrosis). (Underwood, 1999). Reactive Oxygen Species (ROS)/radikal bebas diketahui yang bertanggung jawab terjadinya kerusakan hepar. Karbon tetraklorida merupakan salah satu jenis hepatotoksin yang dapat menghasilkan senyawa radikal bebas. Karbon tetraklorida tertimbun secara besarbesaran dalam lemak tubuh, hati dan sumsum tulang belakang (Klassen, 2001). Karbon tetraklorida diaktifkan oleh enzim sitokrom P450 menjadi radikal triklorometil peroksi $\left(\mathrm{CCl}_{3} \mathrm{O}_{2}{ }^{*}\right)$ yang reaktivitasnya tinggi. Radikal yang dihasilkan dapat menyebabkan autooksidasi pada asam lemak yang terdapat dalam membran sel. Maka dari itu, $\mathrm{CCl}_{4}$ dapat menyebabkan nekrosis yang hebat di dalam sentrobuler hati yang mengandung isoenzim sitokrom P-450 dengan konsentrasi tertinggi (Hodgson and Levi, 2000).

Pengobatan pada hepatitis sangat terbatas maka perlu dilakukan alternatif lain. Salah satunya dengan tanaman obat tradisional yang ada di Indonesia. Dewasa ini masyarakat mulai melirik pengobatan tradisional karena obat tradisional tidak memerlukan biaya yang mahal dan dapat diramu sendiri, selain itu obat tradisional memiliki efek samping yang relatif kecil dibandingkan obat-obat sintetik (Dalimartha, 1997).

Salah satu tanaman obat yang saat ini sedang marak digunakan masyarakat untuk mengobati berbagai macam penyakit yaitu akar pasak bumi. Bagian tanaman yang digunakan dalam pengobatan adalah akar. Akar pasak bumi dapat berkhasiat memperbaiki sel-sel hepar (Panjaitan et al., 2007). Akar pasak bumi kaya akan kandungan kuasinoid. Kuasinoid yang terkandung dalam pasak bumi antara lain eurikomalakton, eurikomanon, dan eurikomanol yang memiliki aktivitas sebagai antioksidan. Kuasinoid merupakan senyawa fenolik yang dapat berperan sebagai donor proton. Mekanisme kerja kuasinoid ini adalah dengan cara melepaskan atom hidrogennya untuk meredam aktivitas oksidan. Selain itu, kuasinoid juga berperan sebagai pemerangkap (scavenger) logam pembentuk radikal bebas (Ang et al., 2002). Berdasarkan 
penelitian yang sudah dilakukan bahwa pasak bumi dapat menjaga kesehatan hati ditunjukkan dengan aktivitas enzim aspartate transminase dan alanin aminotransferase (Panjaitan et al., 2007).

Berdasarkan uraian di atas serta didukung penelitian yang telah dilakukan maka penelitian ini perlu dilakukan untuk mengetahui aktivitas kuasinoid yang terkandung dalam serbuk akar pasak bumi (Eurycoma longifolia Jack.) dalam melindungi hati dari kerusakan yang disebabkan paparan $\mathrm{CCl}_{4}$ sehingga memberikan pengaruh terhadap organ hati tikus jantan yang diinduksi $\mathrm{CCl}_{4}$ dengan melihat aktivitas SGPT-SGOT tikus.

\section{METODE PENELITIAN}

\section{Bahan}

Akar pasak bumi (Eurycoma longifolia Jack.) berasal dari Martapura, Kalimantan Selatan. Bahan penginduksi hepatotoksik adalah $\mathrm{CCl}_{4}$ dari Universitas Gajah Mada. Bahan pembanding Curcumin murni dari Laboratorium Fitokimia, Universitas Ahmad Dahlan. CMC-Na dari Laboratorium Farmasetika, Universitas Ahmad Dahlan. Reagen kit SGPT-SGOT dari DiaSys.

\section{Hewan Percobaan}

Tikus putih jantan galur Wistar umur 2,5-3 bulan (150-250 g) berasal dari Universitas Islam Indonesia. Selama masa adaptasi, tikus diberi makan BR II dan aquades. Tikus dibagi menjadi 5 kelompok yaitu : Kelompok I (normal) diberi aquades. Kelompok II (kontrol) diberi $\mathrm{CCl}_{4} \quad$ (1 $\mathrm{ml} / \mathrm{kgBB}$ ) (Panjaitan et al., 2007) dan olive oil (1:1) i.p (Sreelatha et al., 2009) pada hari ke7. Kelompok III diberi serbuk akar pasak bumi $100 \mathrm{mg} / \mathrm{kgBB}$ p.o. Kelompok IV diberi serbuk akar pasak bumi $200 \mathrm{mg} / \mathrm{kgBB}$ p.o. Kelompok V (pembanding) diberi Curcumin $100 \mathrm{mg} / \mathrm{kgBB}$ p.o (Kumar et al., 2008). Kelompok III, IV, dan V diinduksi $\mathrm{CCl}_{4}$ pada hari ke-7, 1 jam setelah perlakuan terakhir (Gopal et al., 2006).

\section{Jalannya Penelitian}

\section{Evaluasi biokimiawi}

Dua puluh empat jam kemudian, tikus dibedah dan diambil darah dari vena porta hepatica. Darah disentrifuse 3000 rpm selama 15 menit. Serum diambil untuk diuji kadar SGPT dan SGOT menggunakan reagen kit (Panjaitan et al., 2007).

\section{Analisis data}

Kadar SGPT dan SGOT dianalisis dengan Duncan's multiple range test ( $\mathrm{p}<$ $0,05)$.

\section{HASIL DAN PEMBAHASAN}

Tabel I. Aktivitas SGPT-SGOT tikus jantan setelah diinduksi $\mathbf{C C l}_{4}$

\begin{tabular}{cccc}
\hline \multirow{2}{*}{ Kelompok } & DOSIS & \multicolumn{2}{c}{ Aktivitas (U/L) } \\
\cline { 3 - 4 } & (mg/kgBB) & SGPT & SGOT \\
\hline Normal & - & $36,5 \pm$ & $153,7 \pm$ \\
& & $1,732^{\mathrm{a}}$ & $5,902^{\mathrm{a}}$ \\
Kontrol & - & $129,0 \pm$ & $451,5 \pm$ \\
& & $6,055^{\mathrm{d}}$ & $16,759^{\mathrm{e}}$ \\
SAPB & \multirow{2}{*}{100} & $150,0 \pm$ & $369,4 \pm$ \\
& & $5,099^{\mathrm{e}}$ & $11,165^{\mathrm{d}}$ \\
SAPB & \multirow{2}{*}{200} & $113,6 \pm$ & $263,0 \pm$ \\
& & $5,508^{\mathrm{c}}$ & $1,803^{\mathrm{c}}$ \\
Curcumin & \multirow{2}{*}{100} & $60,5 \pm$ & $194,5 \pm$ \\
& & $2,887^{\mathrm{b}}$ & $7,448^{\mathrm{b}}$ \\
\hline
\end{tabular}

Data berupa rata-rata \pm SD. Perbedaan antar kelompok perlakuan dianalisis secara statistik $(\mathrm{P}<0,05)$ dengan Duncan's Multiple Range Test.

Secara umum aktivitas SGPT dan SGOT kelompok normal pada penelitian ini lebih besar dari yang ditetapkan oleh Smith dan Mangkoewidjojo (1988) yaitu aktivitas normal SGPT tikus adalah 17,5-30,2 IU/L dan aktivitas normal SGOT tikus adalah 45,7-80,8 IU/L. Perbedaan hasil analisis tersebut mungkin disebabkan oleh beberapa faktor stres yang dapat terjadi melalui 
peningkatan aktivitas syaraf simpatik perifer (Arakawa et al., 1996), perbedaan bobot tikus, hemolisis,

keadaan fisiologis dan makroenzim yang berbeda, alat dan metode analisis yang digunakan, bahkan perbedaan kit reagen yang digunakan juga dapat mempengaruhi hasil analisis (Hollans and Logan, 1996).

Berdasarkan Tabel I dan hasil analisis statistik dengan Duncan's Multiple Range Test, maka diperoleh hasil sebagai berikut :

\section{Aktivitas SGPT}

Data pada Tabel I terlihat bahwa semua kelompok perlakuan tikus berbeda signifikan $(\mathrm{p}<0,05)$ dengan kelompok kontrol yang artinya kelompok perlakuan serbuk pasak bumi mempunyai efek hepatoprotektif. Hal ini dilihat dari aktivitas SGPT yang menurun dibanding kontrol.

Kelompok normal memiliki aktivitas SGPT paling rendah $(36,5 \pm 1,732)$ jika dibandingkan dengan semua kelompok perlakuan yang mendapat induksi $\mathrm{CCl}_{4}$. Kelompok kontrol hanya mendapat perlakuan $\mathrm{CCl}_{4}$ yang memiliki aktivitas SGPT jauh lebih tinggi $(129 \pm 6,055)$ dibanding kelompok normal $(36,5 \pm 1,732)$. Hal ini dapat disimpulkan bahwa pemberian $\mathrm{CCl}_{4}$ dosis 1 $\mathrm{ml} / \mathrm{kgBB}$ dapat menimbulkan kerusakan hati yang ditandai dengan peningkatan aktivitas SGPT.

Kelompok dosis 100 mg/kgBB $(150 \pm 5,099)$ berbeda signifikan $(\mathrm{p}<0,05)$ dengan kelompok kontrol $(129 \pm 6,055)$. Hasil ini menunjukkan bahwa kelompok dosis 100 $\mathrm{mg} / \mathrm{kgBB}$ tidak memberikan efek hepatoprotektif dilihat dari tidak ada penurunan aktivitas SGPT akibat dari induksi $\mathrm{CCl}_{4}$. Hal ini diakibatkan dari bentuk sediaannya berupa serbuk dimana jumlah zat aktif yang terkandung didalamnya masih sedikit dan masih banyaknya zat pengotor sehingga menyebabkan kelompok dosis 100 $\mathrm{mg} / \mathrm{kgBB}$ belum memiliki efek hepatoprotektif.

Pada kelompok dosis $200 \mathrm{mg} / \mathrm{kgBB}$ $(113,67 \pm 5,508)$ berbeda signifikan $(p<0,05)$ dengan kelompok kontrol $(129 \pm 6,055)$. Hasil ini menunjukkan bahwa pemberian serbuk pasak bumi dosis $200 \mathrm{mg} / \mathrm{kgBB}$ memberikan efek hepatoprotektif karena dapat mengurangi pelepasan SGPT ke dalam darah akibat dari induksi $\mathrm{CCl}_{4}$.

Kelompok dosis $200 \quad \mathrm{mg} / \mathrm{kgBB}$ $(113,67 \pm 5,508)$ dibandingkan dengan kelompok dosis $100 \mathrm{mg} / \mathrm{kgBB}(150 \pm 5,099)$ memiliki kemampuan lebih besar untuk mengurangi pelepasan SGPT akibat induksi $\mathrm{CCl}_{4}$. Dapat disimpulkan bahwa dengan dosis pemberian serbuk akar pasak bumi yang lebih besar maka kemampuannya untuk mengurangi pelepasan SGPT karena induksi $\mathrm{CCl}_{4}$ meningkat.

Kelompok perlakuan curcumin dosis 100 mg/kgBB $(60,5 \pm 2,887)$ jika dibandingkan dengan kelompok kontrol $(129 \pm 6,055)$ yaitu berbeda signifikan. Hal ini dapat disimpulkan bahwa pemberian curcumin dapat memberikan efek hepatoprotektif. Hasil dibandingkan dengan kelompok pemberian serbuk akar pasak bumi dosis $100 \mathrm{mg} / \mathrm{kgBB}$ $(150 \pm 5,099)$ dan $200 \quad \mathrm{mg} / \mathrm{kgBB}$ $(113,67 \pm 5,508)$ terhadap kelompok kontrol $(129 \pm 6,055)$, curcumin memberikan efek hepatoprotektif yang lebih bagus dibandingkan serbuk akar pasak bumi dilihat dari penurunan aktivitas SGPT yang signifikan.

\section{Aktivitas SGOT}

Pada Tabel I dapat diketahui bahwa aktivitas SGOT dari semua kelompok perlakuan hanya berbeda signifikan $(p<0,05)$ jika dibandingakan dengan kelompok kontrol yang hanya diinduksi $\mathrm{CCl}_{4}$. Hal tersebut menunjukkan bahwa semua kelompok perlakuan memberikan efek hepatoprotektif terlihat dari penurunan aktivitas SGOT dalam darah.

Kelompok dosis $100 \quad \mathrm{mg} / \mathrm{kgBB}$ $(369,47 \pm 11,165)$ berbeda signifikan $(\mathrm{p}<0,05)$ dengan kelompok kontrol (451,5 $\pm 16,759)$. Hasil ini menunjukkan bahwa pemberian serbuk pasak bumi dosis $100 \mathrm{mg} / \mathrm{kgBB}$ memberikan efek hepatoprotektif karena dapat 
mengurangi pelepasan SGOT ke dalam darah akibat dari induksi $\mathrm{CCl}_{4}$.

Pada kelompok dosis $200 \mathrm{mg} / \mathrm{kgBB}$ $(263 \pm 1,803)$ berbeda signifikan $(\mathrm{p}<0,05)$ dengan kelompok kontrol $(451,5 \pm 16,759)$. Hasil ini menunjukkan bahwa pemberian serbuk pasak bumi dosis $200 \mathrm{mg} / \mathrm{kgBB}$ memberikan efek hepatoprotektif karena dapat mengurangi pelepasan SGOT ke dalam darah akibat dari induksi $\mathrm{CCl}_{4}$.

Jika dibandingkan antara kelompok perlakuan dosis $100 \quad \mathrm{mg} / \mathrm{kgBB}$ $(369,47 \pm 11,165)$ dan kelompok perlakuan dosis $200 \mathrm{mg} / \mathrm{kgBB}(263 \pm 1,803)$ diketahui pada dosis pemberian $200 \mathrm{mg} / \mathrm{kgBB}$ memiliki kemampuan untuk menghambat kerusakan hati yang lebih besar bila dibandingkan dosis $100 \mathrm{mg} / \mathrm{kgBB}$. Hal tersebut memperlihatkan kemungkinan adanya hubungan antara dosis pemberian dan kemampuan menghambat kerusakan hati karena induksi $\mathrm{CCl}_{4}$ dengan mengurangi pelepasan SGOT kedalam darah.

Kelompok perlakuan curcumin dosis $100 \mathrm{mg} / \mathrm{kgBB} \quad(194,52 \pm 7,448) \quad$ jika dibandingkan dengan kelompok kontrol $(451,5 \pm 16,759)$ yaitu berbeda signifikan. Hal ini dapat disimpulkan bahwa pemberian curcumin dapat memberikan efek hepatoprotektif. Hasil dibandingkan dengan kelompok pemberian serbuk akar pasak bumi dosis $100 \mathrm{mg} / \mathrm{kgBB}(369,47 \pm 11,165)$ dan 200 mg/kgBB $(263 \pm 1,803)$ terhadap kelompok kontrol (451,5 $\pm 16,759)$, curcumin memberikan efek hepatoprotektif yang lebih bagus dibandingkan serbuk akar pasak bumi dilihat dari penurunan aktivitas SGOT yang signifikan.

\section{KESIMPULAN}

Berdasarkan hasil penelitian ini dapat disimpulkan bahwa serbuk akar pasak bumi (Eurycoma longifolia Jack.) memiliki efek hepatoprotektif pada dosis $200 \mathrm{mg} / \mathrm{kgBB}$.

\section{DAFTAR PUSTAKA}

Ang, H.H., Hitotsuyanagi, Y., Fukaya, H., dan Takeya, K., 2002, Quassinoids from
Eurycoma longifolia, Phytochemistry 59; 833-837.

Arakawa H, Kodama H, Matsouka N, Yamaguchi I. 1996. Stress increases plasma activity in rats: differential effects of andrenergic and cholinergic blockades. J Pharmacol Experiment Therapeutics. 280: 1296-1303.

Dalimartha, S., 1997, Seri Agrisehat Ramuan Tradisional Untuk Pengobatan Hepatitis, Penebar Swadaya, Jakarta.

Gopal, N., Sengottuvelu, S., 2008, Hepatoprotective Activity of Clerondendrum inerme Against $\mathrm{CCl}_{4}$ Induced Hepatic Injury in Rats, Fitoterapia 79 (2008) 24-26.

Hodgson E., Levi P.E., 2000, A Textbook of Modern Toxicology $2^{\text {nd }}$ Edition. Boston: Mc Graw Hill Co. pp: 203-204.

Hollands MA, Logan JE. 1966. An examination of commercial kits for the determination of glutamic oxaloacetic transaminase (GOT) and glutamic pyrupic transaminase (GPT) in serum. Canad. J Med. Ass. 95: 303-307.

Klassen, H., 2001, Mechanisms of hepatotoxicity. Raven Press, New York, p. 399. Toxicol.

Kumar, M., Ahuja, M., dan Sharma, S.K., 2008, Hepatoprotective Study of Curcumin-Soya Lecithin Complex, Sci Pharm; 76; 761-774.

Panjaitan, R.G.P., Handharyani, E., Chairul., Masriani., Zakiah, Z., dan Manalu, W., 2007, Pengaruh Pemberian Karbon Tetraklorida Terhadap Fungsi Hati dan Ginjal Tikus, Makara, Kesehatan, Vol. 11, No.1, Juni 2007 : 11-16.

Price, S.A. dan Wilson L.M., 2005, Patofisiologi Konsep Klinis. Edisi 4, diterjemahkan oleh Peter Anugerah, EGC, Jakarta. 
Smith, J,B. Dan Mangkuwidjoyo, S., 1988, Pemeliharaan, Pembiakkan dan Penggunaan Hewan Percobaan di Daerah Tropis, Cetakan Pertama. UI Press, Jakarta.

Sreelatha, S., Padma, P.R., dan Umadevi, M., 2009, Protective Effects of Coriandrum sativum Extracts on Carbon
Tetrachloride-Induced Hepatotoxicity in Rats, Food and Chemical Toxicology, 47 (2009) 702-708.

Underwood, J.C.E., 1999, Patologi Umum dan Sistematik Edisi 2, diterjemahkan oleh Sarjadi, EGC, Jakarta, hal 470471, 474. 